International Journal of Linguistics, Literature and Translation

ISSN: 2617-0299 (Online); ISSN: 2708-0099 (Print)

DOI: $10.32996 / \mathrm{ijllt}$

Journal Homepage: www.al-kindipublisher.com/index.php/ijllt

\title{
An Existential Reading of GB Shaw's Arms and the Man
}

\author{
Md. Ibrahim Khalil 8 (i) \\ Lecturer, Department of English, Pabna University of Science and Technology, Pabna-6600, Bangladesh
}

$\checkmark$ Corresponding Author: Md. Ibrahim Khalil; E-mail: ibrahimkhalil@pust.ac.bd

ARTICLE INFORMATION ABSTRACT

Received: April 04, 2021

Accepted: May 25, 2021

Volume: 4

Issue: 5

DOI: $10.32996 / i j l t .2021 .4 .5 .19$

\section{KEYWORDS}

Existentialism, Selfhood,

Authenticity, Freedom, Identity,

Individuality, Destiny
This paper attempts to analyze George Bernard Shaw's Arms and the Man from existentialistic approach. Adopting a qualitative content analysis method, it concentrates on the fundamental components of existentialism such as searching for the true identity and selfhood, the authenticity of meaningless war and absurd romantic love questioning freedom of choice and decision. Representing the futile Bulgarian war along with its controversial customs and manners, it demonstrates the ultimate destination of the individuals of the play. Additionally, it figures out how the major characters like Sergius and Bluntschli reached the peak of their sincere individuality and refuted their conventional professional advantages and ancestral positions. The study also includes how the downtrodden characters like Louka and Nicola confronted the worthless social system, the erroneous noble lifestyle and the deceitful aristocracy for the search of a distinguished survival.

\section{Introduction}

After Shakespeare, George Bernard Shaw is well-acclaimed to be one of the leading and vibrant playwrights still today. Like other extraordinary plays, Arms and the Man brought this legendary giant to the peak of his literary career as Paul Sawyer (1986) pointed out four important notifications:

Arms and the Man is unique among Shaw's plays in several respects: 1) it was the first of his plays to be produced in commercial theatre; 2) it was the first of his plays to be acted in America; 3) it is the only one to translated into Basic English; and 4) it is the only Shaw play to be printed with three different final curtain lines. This brief note will address itself to the last "respect" (p.123).

Along with these factual reputations, the original last line of the play had been elaborately discussed where Sawyer noted, 'The original last line is "What a man! What a man!" It is found in Shaw's handwritten copy of the play now in the British Museum. It is also in a typescript of the play, on the title page of the first act on which Shaw has written his name; this typescript is now in possession of the Beinecke Rare Book and Manuscript Library of Yale University" (1986, p. 123). Fatemeh Azizmohammadi and Zohreh Tayari (2014) criticized Arms and the Man from two perspectives. Firstly, they commented on class conflict prevailed in the entire society, "In Arms and the Man, class struggle is shown by introducing of play different characters" (p. 7). Captain Bluntschli never shows his behavior like higher class although he has a massive amount of wealth and fortune. But Raina Petkoff is different in nature and attitude, "Raina Petkoff is one of the George Bernard Shaw's most happy heroines in his plays. She belongs to high class of society" (Azizmohammadi \& Tayari, 2014, p.7). The important fact to be noted here is that the higher class intensively controlled the lower classes through their power, dominance and tyrannical actions. Besides, gender concern has also been visible in the play:

George Bernard Shaw pictures gender role in characters, Louka, Catherine, Sergius, and other. There is masculinity in Louka's character while annoying Nicola. She reveals her control through her interaction with Sergius. Mrs. Petkoff also shows masculinity in controlling house hold works in absence of her husband Mr. Petkoff (Azizmohammadi \& Tayari, 2014, p. 7).

\section{K C AL-KINDI CENTER $\mathbf{R}$ D FOR RESEARCH AND DEVELOPMENT} Your gateway to world-class research

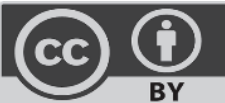

Published by Al-Kindi Center for Research and Development, London, United Kingdom. Copyright (c) the author(s). This open access article is distributed under a Creative Commons Attribution (CC-BY) 4.0 license 
Shahzad Ahmad Siddiqui and Syed Asad Raza (2012) evaluated the play both from realistic and idealistic ideas: In this play, Shaw attacks genially the romantic notions of war and love. He has adopted a realistic approach in depicting every day activities which were common those days. Here Shaw attacks the social follies of society in order to bring a positive change for which he received criticism. Shaw rejects romanticism in order to embrace realism (p.48).

Dipti H. Mehta (2016) pointed out anti-romantic sense, "The play is anti-romantic because in it Shaw has attacked the dreamy veneration of life and it is also a comedy because in it he has open to the elements and ridiculed the worthlessness of romantic love and valiant concept of conflict" (p. 461). In fact, the play portrays the inherent image of human kind, "Shaw with his brilliant intelligence and humour rips off the quixotic illusion of war and love and shows what they really are" (Mehta, 2016, p.462). Farhana Haque (2016) contextualized psychoanalytical approach where she related Raina Petkoff's changing attitudes towards love and affection:

Raina's conflicts between her Id, Ego, Superego, and her disappointment towards Sergius made her to re-arrange her own opinions. As a dramatic person in the play she has experienced a characteristic change regarding her sense of love. After meeting with Bluntschil, Raina Petkoff's stereotype concepts of war and hero became changed (p.60-61).

J. Scott Lee (1986) incorporated the comic unity of Arms and the Man dividing two particular sections, "We can divide Arms and the Man into two sections which reflect potentialities for the action and the comic action itself. The first section is an extended "prologue." It runs to the point in Act II when Sergius and Louka are alone. The second is the comic action proper. It begins with Sergius's advance towards Louka" (p.102). Calvin T. Higgs, Jr. discussed the use of Vergil's Aeneid in Arms and the Man:

To examine the play in relation to Vergil's epic is to investigate the link established between the playwright and the play in its development stages. Desiring to produce a literary expression of his developing philosophy, Shaw was drawn to those elements of Vergil which seemed to demonstrate a positive determinism operating on human actors $(1976$, p. 3).

The significance of this paper is that it has analyzed Shaw's Arms and the Man from existentialistic view. It also highlights what sort of struggle both higher and lower class people usually face to meet the inherent self and individuality that question their genuine essence of existence.

\section{Theoretical Framework}

Due to the approach of modern scientific lifestyle, the world frequently experienced frustration provoking ungodly face of war to be a substantial means of profit maximization. In this regard, Christopher Panza and Gregory Gale's specific remark on the breakdown of traditional ideals and the collapse of spiritual existence can be asserted, "During this period, people began to feel disconnected from the traditional belief systems that had helped them make sense of the world and of their lives. In these conditions, people may not literally commit suicide, but a kind of spiritual death - a spiritual suicide - becomes a very real danger" (2008, p. 9). The essence of human existence and essential dignity had been pushed before hazardous threat. Additionally, this self-guided circumstance entangled life with absurd ways and consequences. For instance, people began to lose their moral health and mutual relationship based on true love, loyalty and compassion.

Incorporating these argumentative issues George Bernard Shaw launched one of his master pieces Arms and the Man under the second volume, tilted Plays of Pleasant and Unpleasant in 1898. As a matter of fact, this three-act play vehemently exposed the Bulgarian-Serbian war of 1880 s capturing a sharp condemnation against the traditional concept of romantic love and intentionally spawned war. In an "Introduction" written for the play Arms and the Man Tuhin Mukherjee (2006) discussed the rooted issues to have a clear idea, "Shaw's play, set in the early days of a new nation, Bulgaria, attempts to distinguish between true and false concepts of heroism, virtue, honour and national dignity" (p. ix). Basically, in this play, Shaw examined Bulgarian usual customs, norms and values from the disparate questioning lens. In particular, he pointed out that worthless war not only abolished human peaceful habitation and livable infrastructure but also annihilated the long sustained conventional principles, philosophies and the least spirit of existence.

Shaw's principal concern of existentialism determined the true dignity and successful existence of human being considering all the important issues related to life. Marcel coined the term "Existentialism" in 1945 for the first time. Due to debates on the basic concepts, there prevail complexities in the exact definition of existentialism. Considering these controversial issues, Panza and Gale (2008) recommended the core demand of existentialism, "According to the existentialists, however, you want to live a full and authentic human life, a rewarding and fulfilling life that embraces your human dignity. For that, they say, you need, at a minimum, oxygen and a healthy dose of existentialism" (p.9). This statement proves how important existence is to determine a meaningful and authentic life ensuring proper dignity and respectful position in the universe. Without authentic existence man feels suffocation to breathe for a better survival. Sartre (1948) impartially focused on uncertainties and secluded condition of human being, "This existentialism does not depend upon a notion of the nature of man, but this time it is not a nature that has pride in itself, but one that is fearful, uncertain and forlorn" (p. 57). 
Inviting diverse characters like Sergius, Raina and Bluntschli, Shaw stirred a number of socially controversial and economic subjects injecting spontaneous sense of humor fervently. In front of Shaw's neutral judgment, nobody possessed superior or inferior custody. He observed everyone's ins and outs analyzing each step they took and every word they delivered from a critical analysis. The way he glorified one's prestige and munificence, the same way he downgraded one's asininity, transgression and misdemeanor.

\section{Discussion}

In the realm of existentialism, the position and recognition of human species is keenly prioritized. Along with proper distinctiveness, it talks about valid authenticity of public actions and motivations to go forward. It also looks for the problems of true identity and humanity studying individuals' unaffected freedom of choice and decision. Besides, existentialist approach focuses the facticity of existence, conditions of anxiety and the search of ultimate destiny and reality. In order to analyze Shaw's Arms and the Man from existentialistic perspective, the followings issues had been selected and argued.

\subsection{Struggle towards Self and True Identity}

Achieving "Self" is one of the major components of existentialism. John Macquarrie's argument of "Self" can be noted here for a better understanding, "To gather up the whole self into a concentrated act of will is really and authentically to become oneself and to be rescued from the scattering and dissolution of the self in trivial concerns and in the crowd" $(1973$, p. 216). Furthermore, selfhood requires the confirmation of conscious self-choice and true identity. Without authentic identity one cannot reach the peak of selfhood. In this concern, Thomas R. Flynn (2006) necessarily includes Satre's observation to form relevance, "Sartre argues that our original choice is our futile pursuit of being consciously self-identical. We have seen that the quest for identity is on a collision course with our consciousness as non-self-identical" (p. 76). The play Arms and the Man represented a concrete search for self-identity.

Interestingly, both Louka and Nicola could not accept their identity as servants. They expected an authentic treatment and acknowledgement as part of widely recognized human civilization. The man servant Nicola worked in the Petkoff family for a better survival in future. Like the soldiers in the battle field, he had to be busy with various household chores. At the end of the day, soldiers got designation, dignity and honorarium to be proud of. On the other hand, both Nocola and Louka had been treated so unequally and disgracefully that they never found the slightest dignity as human being. In fact, they were assaulted and disgraced for a sudden silly mistake. Shaw stated Major Petkoff's comment, "Scoundrel! He's got out of hand while I was away. I'll teach him. Infernal blackguard! The sack next Saturday! I'll clear out the whole establishment" (2006, p.113).

Sergius had done a severe crime for the unprofessional cavalry charge. For this wrongly guided mission, Sergius was supposed to face court martial law. As a result, he lost his further promotion. Even then, the Petkoff family never treated him badly or otherwise. Rather, they celebrated his return with utmost devotion and honor. This discriminative attitude raised questions to the base of true identity. As a part of similar human kind both Nicola and Louka did not receive this disparity and negligence. Macquarrie (1973) added Kierkegaard's understanding, "For Kierkegaard there is no human and no rational solution to the dilemma of existence. There is no human solution, for man's finitude and his sinfulness make it possible for him to effect his own salvation" (p. 217). Nicola's problematic identity of "Servant-hood" usually haunted him to think of his position. It is true that he knew the contribution of Petkoff's family in his life. Nonetheless, this discriminative behavior created a perpetual dissatisfaction in the deep of his heart. Shaw remarked Nicola's frustration, "I'm a human being. I get tired of being servant occasionally" (Shaw, 2006, p.135). But the maid servant Louka was different not only in nature and attitude but also in action and self-consciousness. While Nicola accepted this intolerable reality, Louka opposed forcibly defying her social distinctiveness. With a view to downgrading Louka's spirit Nicola always suggested, "Well, you take my advice and be respectful; and make the mistress feel that no matter what you know or dont know, she can depend on you to hold your tongue and serve the family faithfully "(Shaw, 2006, p.75).

The play represented Louka as a straightforward, desperate and disobedient girl. She never believed in the conventional set up of the world. That is why she found no reason to follow Nicola's cautious advice. In her reply Louka clearly expressed the force of her free will, "You II never put the soul of a servant into me" (Shaw, 2006, p.75). Louka not only went against the so called faulty and vacuum customs and norms of Bulgaria but also contrasted Nicola's long cherished plan. Incidentally, the play revealed that Nicola wanted to open a shop in Sofia with Petkoff family's wholehearted assistance and desired to marry Louka in future. But he could not stand before Louka's "Self" and "Spirit" that confirmed her bold identity, "You shall never be master in mine" (Shaw, 2006, p.136). The striking incident happened when Sergius intended to seduce Louka in the absence of his betrothed Raina. Louka cautiously rejected the lecherous call of Sergius and became humiliated desperately. Shaw pointed out the ill remark of Sergius, "That shews that you are an abominable little clod of common clay, with the soul of a servant" (Shaw, 2006, p.100). As a servant, Louka could tolerate Sergius's maltreatment as she had the risk to lose her job and future. But she was so desperate and 
daring that she immediately showed her intense concern of "Self", "But I don't care, now Ive found out that whatever clay I'm made of, youre made of the same" (Shaw, 2006, p.100).

Louka was so courageous and unafraid that she claimed to call Raina by name no matter what position she held. Major Sergius had also been motivated by the apprehension of self and true identity. He had enough possibility to prosper gaining better position in the military. Yet he was not happy with his profession although he had well acknowledged designation and popularity. Sergius understood that soldering was a business like cowardly and immoral profession to attack the weak and wretched. Therefore, he had no intention to continue this job anymore, "But I have no ambition to shine as a tradesman" (Shaw, 2006, p.100). Like Petkoff, Catherine and Raina, he had also the sense of pride for his enormous wealth and prestigious position. Earlier Sergius once treated Louka as a detestable servant. Finally, he learnt how to treat someone like Louka as human being throwing out all his false conception and faulty ideals and extended his hand to marry. Shaw reported his straightforward answer, "But (vehemently) I will not be coward and a trifler. If I choose to love you, I dare marry you, inspite of all Bulgaria. If these hands ever touch you again, they shall touch my affianced bride" (Shaw, 2006, p.144). When Catherine instigated to remind the previously bounded words, Sergius immediately protested, "Nothing binds me" (Shaw, 2006, p.161). By this comments, Sergius proved his conscious of "Self" and true identity.

Captain Bluntschli was also directed by the sense of "Self" although he owned huge amount of property ancestrally including two hundred horses and seventy carriages. Blunstchli himself gave a clear description of his enormous wealth, "I have nine thousand six hundred pairs of sheets and blankets, with two thousand four hundred eider-down quilts. I have ten thousand knives and forks, and the same quantity of dessert spoons"(Shaw, 2006, p.166). Nevertheless, Bluntschli was not happy as he desired to do something by his own strength. From childhood, Bluntschli understood his "Self", "I ran away twice when I was a boy. I went into the army instead of into my father's business" (Shaw, 2006, p.162). This statement showed how remarkably Bluntschli moved forward in search of "Self".

\subsection{War and Romantic Love: Instrument of Inauthenticity and Meaninglessness}

Existentialism denotes an interrogation of authenticity. There are different definitions of authenticity. Taylor Carman (2006) deeply analyzed the basics of authenticity, "The concept of authenticity is one of the most important and fruitful ideas to emerge from the existential tradition in philosophy, especially in the works of Kierkegaard, Heidegger, and Sartre" (p. 229). Besides, the conception of these existentialists, Golomb Jacob (1995) identified authenticity as something out of intended language, "The notion of authenticity, it seems, signifies something beyond the domain of objective language, while the notions of sincerity and honesty have to do with attributes to which language can refer directly"(p.15). However, the play Arms and the Man questioned the legitimacy of an unscrupulous war demonstrating its controversial necessity and hollowness. Major Sergius Saranoff, a tall romantically handsome protagonist of the paly, commented on the profession of soldiering, "I am no longer a soldier. Soldiering, my dear madam, is the coward's art of attacking mercilessly when you are strong, and keeping out harm's way when you are weak"(Shaw, 2006, p.88). This statement proves that war is a self-motivated game between weak and strong.

In the surface level, war refers to a notion of battle against vice and virtue in term of establishing peace and solidarity. But in the play, war is something trade like business having the calculation of profit and loss. On the other hand, the fifty year old Major Petkoff expressed his long experienced opinion, "I suppose soldiering has to be a trade like any other trade"(Shaw, 2006, p.88). Another important point came from Bluntschli's observation of the value of soldiers' lives. Like others, the soldiers should have the choice to live as long as they can. Profession is important for life to survive. When Bluntschli took shelter in Raina's bedroom climbing the water pipe, she insulted him, "Some soldiers, I know, are afraid to die" (Shaw, 2006, p.43). This statement depicts the fact that soldiers are the dying components. They have come to the world only to die. If the war itself is regarded as a trade like profession, then soldiers should have the right to live long. Shaw reported Bluntschli's life experience, "All of them, dear lady, all of them, believe me. It is our duty to live as long as we can" (Shaw, 2006, p.43). By this comment, Shaw brought this unresolved truth to light.

Like self-motivated war, romantic love lacks authentic base in existentialist approach. Arms and the Man can be a better example for the rise and fall of faulty romantic love. The play started with the introduction of Sergius as the extraordinary heroic figure. By reading the romantic adventures and beautiful poetry of Byron and Pushkin, Raina developed a sense romantic love. Therefore, Sergius appeared before her as an outstanding personality. Raina worshipped the portrait of Sergius and called him the hero of her soul, "Yes: I was only a prosaic little coward. Oh, to think that it was all true! That Sergius is just as splendid and noble as he looks! That the world is really a glorious world for women who can see its glory and men who can act its romance!"(Shaw, 2006, p.36) Since Raina was Sergius's betrothed, she was supposed to be existed to think of him. But Raina's mother over excitation surprised all. Vielhauer (2019) assumed, "Sergius' cavalry charge, the act of heroism Raina and her mother celebrate, is actually later revealed to be a blundering mistake. Here, Shaw's use of melodramatic conventions allows him to work within a structure that he can then challenge" (p. 3). 
At the end of the play, audience experienced a different Sergius who was highly interested in the maid servant of the house rather the heroine. The conspicuous incident happened when Raina left him for five minutes. Sergius tried all the probable ways to grasp Louka in his arms. He introduced the discussion of higher love intentionally so that Louka would participate. That would be the reliable way to attract Louka's concentration. Later Sergius questioned something strange towards a maid servant, "Do you consider my figure handsome, Louka?"(Shaw, 2006, p.30) In fact, Sergius thought Louka to be a dull headed girl who could never understand his intention. The atmosphere and position was not in Louka's favor. Still, she tried to distract the award situation answering something else. When Sergius failed to impress Louka, he fluctuated from his previous stand and considered Louka to be a devilish creature, "You are a provoking witch, Louka" (Shaw, 2006, p.97).

Surprisingly, this is the same Sergius who impressed Raina applying his false affection, "Dearest: all my deeds have been yours. You inspired me. I have gone through the war like knight in a tournament with his lady looking down him!" (Shaw, 2006, p.93) The love and dedication Raina expressed towards Sergius throughout the play could not meet the end. Finally she decided to marry Bluntschli. It was true that she could not tolerate the relationship between Louka and Sergius. As a part of her revenge she might take the final decision to reject Sergius. Still, there remained some issues which produced questions towards Raina's actions. Firstly, the encounter between Raina and Bluntschli in her bedroom can be granted for accidental reason. But Raina's action of keeping her photograph into the coat's pocket raised question. Major Petkoff revealed, "Your photograph, with the inscription: Raina, to her Chocolate Cream Soldier: a Souvenir"(Shaw, 2006, p.156).

When Raina came to know the marital status of Bluntschli, she became very excited. In addition, Raina's confusing answer towards her mother also created suspicion. In the play, Catherine instigated Raina, "Tell me the truth, Raina. How long was he in your room before you came to me?"(Shaw, 2006, p.103) Surprisingly, Raina lied that she lost the memory, "Oh, I forget" (Shaw, 2006, p.104). Facing reported question of Catherine, Raina's further answer was more controversial, "No. Yes: I think he must have been there then" (104). The indication of baseless love had been depicted in Sergius's final observation where he compared biased war with faulty love, "Oh, war! War! The dream of patriots and heroes! A Fraud, Bluntschli. A hollow sham, like love" (Shaw, 2006, p.148). Through this statement Sergius clarified the groundless relationship of the so called Bulgarian society.

\subsection{Freedom of Choice and Decision}

Freedom is another basic element of existentialism. In order to clarify the understanding of freedom and its authenticity, Flynn (2006) proposed, "Freedom constitutes the ultimate value for the existentialists just as authenticity is their primary virtue" (p.79). Contrarily, Macquarrie pointed out the analysis of two existentialists naming Kierkegaard and Sartre, "Sartre is just as insistent as Kierkegaard that freedom and existence are indistinguishable. One does not first exist and then become free; rather, to be human is already to be free" (1973, p.177).

In the play Arms and the Man, Raina could not exercise her freedom of choice. She had to depend on the opinion of her parents. If they supported, only then she could move forward. Her mother Catherine had motivated her intensely to worship Sergius, "Oh, if you have a drop of Bulgarian blood in your veins, you will worship him when he comes back" (Shaw, 2006, p.34). This statement desperately goes against someone's concrete freedom. As an individual, Raina must possessed freedom of choice and decision. Catherin's reported interruption and instigation made her angry and furious. Shaw asserted Raina's condition in her impulsive reply, "Oh, I know Sergius is your pet. I sometimes wish you could marry him instead of me. You would just suit him. You would pet him, and spoil him, and mother him to perfection" (Shaw, 2006, p.104).

The important thing to be noted here is that Raina is the daughter of the most aristocratic family in Bulgaria. Therefore, she should have alternatives to choose by herself. Shaw stated Raina's utmost anger, "I always feel a longing to do or say something dreadful to him-to shock his propriety- to scandalize the five senses out of him. [To Catherine, perversely] I dont care whether he finds out about the chocolate cream soldier or not" (Shaw, 2006, p.104). The fact is that Raina did not bring Bluntschli. Even she did not have any knowledge abouit this Swiss soldier. He entered into her room without her consent terrifying with a pistol in hand.

\subsection{The Ultimate Destiny of the Individual}

The ultimate destiny of an individual is unpredictable and nonterminating. About existential individuality and authenticity, Flynn (2006) commented, "Authenticity is a feature of the existentialist individual. In fact, existential individuality and authenticity seem to imply one another. One is no more born an individual (in the existentialist sense) than is one born authentic" (p.74). Analytically, existentialists find no meaning or purpose of life. In the very beginning of the play, Louka was only a maid servant having no distinguished social position. She did not belief in Nicola's concept of higher class. Rather, she protested when Nicola disclosed the truth "Child: you dont know the power such high people have over the like of you and me when we try to rise out of our poverty against them" (Shaw, 2006, p.74). Hitherto, Louka shifted her class not by force but by extraordinary individuality, "I would marry the man I loved, which no other queen in Europe has the courage to do" (Shaw, 2006, p.142). Contrarily, Sergius had wealth and prestigious position in army. He could prosper in military. But he was destined in à way that he collapsed from 
his social stratification. In terms of Bluntschli, things could be different as he was the son of a great businessman. But he devoted his life for fifteen years in barrack. On the contrary, Raina had no idea about Bluntschli. Even she never met him before the night Bluntschli entered into her bedroom. She wholeheartedly loved Sergius. But she could not change her ultimate destiny.

\section{Conclusion}

In Arms and the Man, Shaw efficaciously framed simple, sharp and spontaneous conversations to construct a pleasant platform. Using this reliable ground, each character of the play flourished unhesitatingly fronting diverse problematic situations. Contextually, both love and war had been used here as two basic courses of exam where everyone participated. By the time being, Shaw analyzed the facts of human existence confirming respectful livelihood. Furthermore, he searched the very basic prerequisite of life "The Self" no matter what designation the personality possessed or not. In order to determine true human existence, Shaw put his characters face to face towards life and reality, the traditional and unusual situations and the perception of higher and lower.

Arms and the Man attracted scholars from different parts of the world. A good number of scholars contributed their valuable ideas, innovative explanations and comprehensive analyses to this play. Significantly, this paper incorporated a new dimension to interpret the play from existentialistic perspective.

The fact to be noted here is that the study covered several basic components of existentialism such as true self and identity, meaninglessness, freedom of choice and decision facing the eventual destiny of the individuals. Therefore, it is expected that future researchers will explore the play demonstrating more substantial pictures of existentialism.

\section{References}

[1] Azizmohammadi, F., \& Zohreh,T. (2014). Sexism or gender differentiation and class differentiation in George Bernard Shaw's Arms and the Man. International Journal of Literature and Arts, 2(1), 6-9. doi: 10.11648/j.ijla.20140201.12.

[2] Carman, T. (2006). The Concept of Authenticity. A Companion to Phenomenology and Existentialism. Edited by Hubert L. Dreyfus and Mark A. Wrathall. Blackwell Publishing, 229-239.

[3] Flynn, R. (2006). Existentialism: A Very Short Introduction. Oxford University Press.

[4] Golomb, J. (1995). In Search of Authenticity: From Kierkegaard to Camus. Routledge.

[5] Haque, F. (2016). Raina Petkoff's Changing Attitudes towards Love: A Study of Her Defense Contrivance Based on Psychoanalytical Analysis. International Journal of English, Literature and Social Science (IJELS), 1(1), 58-61.

[6] Higgs, C. (1976). Shaw's Use of Vergil's Aeneid in Arms and the Man. The Shaw Review, 19(1), 2-16. http://www.jstor.org/stable/40682417

[7] Lee, J. (1986). COMIC UNITY IN ARMS AND THE MAN. Shaw, 6, 101-122. http://www.jstor.org/stable/40681175

[8] Macquarrie, J. (1973). Existentialism. Penguin Books.

[9] Mehta, M. (2016). Arms and the Man - An Anti-Romantic Comedy. Indian Journal of Research, 5(3), 461-462.

[10] Mukherjee, T. (2006). Introduction. Arms and the Man. By George Bernard Shaw. Friends Book Corner, vii-xvi.

[11] Panza, C., \& Gregory, G. (2008). Existentialism for Dummies. Wiley Publishing, Inc.

[12] Sartre, P. (1948). Existentialism and Humanism. Translated by Philip Mairet. Eyre Methuen LTD.

[13] Sawyer, P. (1986). THE LAST LINE OF ARMS AND THE MAN. Shaw, 6, 123-125. http://www.jstor.org/stable/40681176

[14] Shaw, B. (2006). Arms and the Man. Friends Book Corner.

[15] Siddiqui, A., \& Syed, R. (2012). Realism in Arms and the Man: A Comparative Study - Realism and Idealism. International Journal of Humanities and Social Science, 2(12), 44-49.

[16] Vielhauer, M (2019). Romanticism and Anti-Romanticism. On Stage. Directed by Stefan Novinski. University of Dallas, 3-4. 